\title{
Lupus anticoagulant (LA) in pregnant women with history of recurrent fetal loss
}

\author{
This article was published in the following Dove Press journal: \\ Journal of Blood Medicine \\ I June 201 I \\ Number of times this article has been viewed
}

\section{JA Olaniyi \\ SA Olomu \\ OA Finomo}

Department of Haematology, University College Hospital, Ibadan, Nigeria
Correspondence: John Ayodele Olaniyi Department of Haematology, University College Hospital, Ibadan, Nigeria Tel +234 802345I509

Email ayodeleolaniyi8@gmail.com
Abstract: The frequency of LA in 50 women with intact pregnancy, age range 26 to 39 years, but with past history of at least 2 lost pregnancies, was determined using coagulation-based assays. Most (68\%) of the pregnant women were in the first trimester. Venous blood $(4.5 \mathrm{~mL})$ carefully collected from each of the subjects and also the controls (normal relative donors) was put in $0.5 \mathrm{~mL}$ of $3.8 \%$ citrate (ratio 9:1). The blood was quickly centrifuged at $1500 \mathrm{~g}$; plateletpoor plasma was separated and frozen at $-30^{\circ} \mathrm{C}$ until analyzed. The control plasma was pooled and dispensed in $2 \mathrm{~mL}$ aliquots. Partial thromboplastin time with kaolin ( $\mathrm{PTT}_{\mathrm{k}}$ ) (against the control samples for comparison) and kaolin clotting time (KCT) were determined on each of the test samples using standard laboratory procedures. Prolonged $\mathrm{PTT}_{\mathrm{k}}$ was obtained in 36 patients $(72 \%)$. KCT was obtained through mixtures of patients' plasma with pooled control plasma $(\mathrm{P}: \mathrm{C})$ at 100:0; 0.8:0.2; 0.6:0.4; 0.5:0.5; 0.4:0.6; 0.2:0.8; 0:100; and lin-lin graph paper was used to plot out each of these dilutions against their respective clotting time in seconds. The interpreted graph showed that 12 (24\%) had LA, while 3 (6\%) had LA with cofactor. This high frequency necessitates regular screening for LA in pregnant women with a history of recurrent fetal loss at any gestational age.

Keywords: prevalence, pregnancy, recurrent fetal loss, lupus anticoagulant, coagulation-based assays

\section{Introduction}

The lupus anticoagulant (LA), most commonly an immunoglobulin, is an immediateacting coagulation inhibitor found in a variety of autoimmune disorders and sometimes found in otherwise healthy individuals. ${ }^{1}$ It appears to be directed specifically against the phospholipids moiety of prothrombinase complex formed by the interaction of factors Xa, Va, platelet phospholipids, and calcium. ${ }^{2}$ It was first described in $1952 .{ }^{3}$ and its strong association with thromboembolic phenomenon, spontaneous miscarriage, and stillbirth was established. ${ }^{4-6}$

LA is an acquired autoantibody that binds to phospholipids' active coagulation factors, which slows down the rate of thrombin generation and therefore retards clot formation in vitro, ${ }^{6}$ but promotes both venous and arterial thrombosis in vivo. ${ }^{7}$ This paradoxical association between in vitro anticoagulant effect and in vivo prothrombotic state activity of this autoantibody is not fully understood.

While antiphospholipid syndrome (APS) is known to be one of the most important causes of acquired hypercoagulable states $^{8}$ and specifically causes late pregnancy loss, some studies found an association of 7\% to $10 \%$ between recurrent spontaneous abortions in the first trimester and LA. ${ }^{6}$ 
Placental vessel thrombosis with ischemia, ${ }^{9}$ which starts early in pregnancy, and spiral artery vasculopathy, ${ }^{10}$ which begins at about 8 weeks and is complete by 16 to 20 weeks of gestation, are regarded as the causes of pregnancy loss.

Information about LA frequency in pregnant women with history of recurrent fetal loss is sparse in this part of the world, hence this study.

\section{Materials and methods Subjects}

Before the study began, approval was obtained from the ethical review committee of Oyo State Hospitals Management Board and informed consent from individual patients. Fifty women with intact pregnancy but who had had at least two previous unexplained pregnancy losses (ie, at least gravida 3), irrespective of their gestational age, were consecutively recruited into the study at the antenatal clinic of Adeoyo Maternity Hospital, Yemetu, Ibadan between January and April 1998. The age range was 26 to 39 years (average 31.6 years). Their antenatal records did not show comorbidities attributable to pregnancy loss.

\section{Sample collection}

Venous blood $(4.5 \mathrm{~mL})$ was carefully collected through clean venupucture from each patient into a clean plastic tube containing $0.5 \mathrm{~mL}$ of $3.8 \%$ trisodium citrate $(9$ parts venous blood: 1 part anticoagulant). After thorough but gentle mixing, the sample was centrifuged for 15 minutes at $1500 \mathrm{~g}$ at $25^{\circ} \mathrm{C}$ and platelet-poor plasma (PPP) was immediately and carefully aspirated and stored on ice in the freezer at $-20^{\circ} \mathrm{C}$ prior to use.

Using a similar method PPP was obtained from each of the individual's voluntary relative donors, which was pooled but discounted and stored in $2 \mathrm{~mL}$ aliquot at $-20^{\circ} \mathrm{C}$.

\section{Coagulation tests}

Prothrombin time was determined by the original technique by Quick. ${ }^{11}$ Also partial thromboplastin time with kaolin was performed using the original method by Proctor and Rapparport. ${ }^{12}$

A kaolin clotting time (KCT) test, which is essentially an activated partial thromboplastin test but without any added phospholipid, was performed as previously described by Exner et a ${ }^{13,14}$ by preincubating $0.2 \mathrm{~mL}$ of citrated plasma with $0.1 \mathrm{~mL}$ of kaolin suspension $(20 \mathrm{~g} / \mathrm{L}$ in tris buffer $\mathrm{pH}$ 7.4) for 3 minutes at $37^{\circ} \mathrm{C}$.
Table I Dilutions of normal patient plasma

\begin{tabular}{ll}
\hline Normal plasma & Patient plasma \\
\hline $100 \%$ & $0 \%$ \\
$90 \%$ & $10 \%$ \\
$80 \%$ & $20 \%$ \\
$50 \%$ & $50 \%$ \\
$20 \%$ & $80 \%$ \\
$10 \%$ & $90 \%$ \\
\hline
\end{tabular}

\section{Method}

A mixing experiment was performed using dilutions of normal patient plasma prepared as shown in Table 1. Kaolin is added and then calcium to initiate coagulation. The KCT is the time from adding calcium to clot formation.

$\mathrm{KCT}$ ratio, ${ }^{14}$ ie, a ratio of $\mathrm{KCT}$ at $20 \%$ test plasma to $\mathrm{KCT}$ at $100 \%$ normal control plasma, was then calculated for each of the samples

$$
\frac{\text { KCT }(80 \% \text { normal: } 20 \% \text { test })}{\text { KCT } 100 \% \text { normal: }}=\geq 1.2
$$

A ratio of $\geq 1.2$ is considered positive for a lupus anticoagulant.

\section{Results}

Out of the 50 recruited pregnant women, 34 (68\%), 7 $(14 \%)$, and $9(18 \%)$ were in first, second, and third trimester, respectively.

Table 2 summarizes the outcome and interpretation of results in 50 pregnant women with history of fetal loss. The percentage dilution of neat/Test (N/T) plasma was plotted against time on a Lin-Lin graph for the 15 patients (30\%) that had prolonged KCT; of these, 12 (24\%) showed graphical evidence of LA in circulation and $3(6 \%)$ showed graphical evidence of LA as well as deficiency in the cofactor necessary for full inhibitory effect.

\section{Discussion}

The APS is defined by the presence of antiphospholipid antibody or LA, usually in high titer, and any or all of the following clinical events: recurrent thromboses, recurrent fetal losses, and thrombocytopenia. ${ }^{15}$ Also Livedo reticularis

Table 2 Outcome of partial thromboplastin time with kaolin $\left(\mathrm{PTT}_{\mathrm{k}}\right.$ ) and kaolin clotting time (KCT) in 50 pregnant women with recurrent pregnancy loss

\begin{tabular}{lllll}
\hline Tests & $\mathbf{n}$ & $\begin{array}{l}\text { Within } \\
\text { normal }\end{array}$ & $\begin{array}{l}\text { Mild } \\
\text { prolongation }\end{array}$ & $\begin{array}{l}\text { Very } \\
\text { prolonged }\end{array}$ \\
\hline PTT $_{k}$ & 50 & 14 & - & $36(72 \%)$ \\
KCT & 50 & 35 & $3(6 \%)$ & $12(24 \%)$ \\
& & & $($ LA + cofactor) & (LA in circulation) \\
\hline
\end{tabular}

Abbreviation: LA, lupus anticoagulant. 
is considered to be an additional marker for the disease. ${ }^{16}$ Antiphospholipid antibody is identified either with an enzyme linked immunosorbent assay (ELISA), which commonly uses cardiolipin as the phospholipid's antigen or by finding an LA with clotting tests. While ELISA for antiphospholipid antibody is known to be sensitive, but not very specific for predicting clinical events, LA with clotting tests, on the other hand, are specific but less sensitive. ${ }^{17}$ Although antiphospholipid antibody thus occurs in a variety of situations in healthy individuals, in association with infections such as syphilis, in HIV-1, hepatitis C, and cytomegalovirus and in relation to medications, autoimmune antiphospholipid antibodies have higher titers and are more commonly of IgG isotype (mainly IgG2 and IgG4 subclasses), have higher avidity, and require presence of a cofactor. ${ }^{15,17,18}$ APS is a heterogeneous disorder both in terms of clinical manifestation and the range of autoantibodies.

Although antiphospholpid antibody causes prolongation of phospholipid-dependent clotting tests in vitro, it causes thrombosis in vivo. Different mechanisms thought to be responsible for this in vivo thrombosis and ischemia include inhibition by antibodies of antithromb-independent anticoagulant mechanisms, activated protein $\mathrm{C}$, and inhibition of fibrinolysis. ${ }^{19}$ Other mechanisms are increased plasma concentration of soluble tissue factor and tissue pathway inhibitor, increased monocyte expression of tissue factor, and procoagulant activity in some patients with the syndrome. ${ }^{20}$ Also, the autoantibody can inhibit prostacyclin secretion and promote release of von Willebrand factor by endothelia cells in vitro. ${ }^{21,22}$ Finally, platelet activation also plays a role in APS, particularly in arterial thrombosis. Therefore a thrombotic basis for pregnancy failure in APS is highly supported by the finding of decidual vasculopathy and placental infarction observed by Rand et al. ${ }^{23}$

In the present study, $60 \%$ of the patients have prolonged prothrombin time (18\% mildly prolonged and $42 \%$ severely prolonged). This phenomenon has been observed in the past that LA occasionally increases the prothrombin time, and in turn the international normalized ratio, and therefore monitoring anticoagulation with warfarin becomes difficult. ${ }^{24,25}$

Also our results agree with those of Haywood and Brown ${ }^{26}$ who observed approximately $10 \%$ to $15 \%$ presence of LA in all the patients undergoing recurrent pregnancy loss.

The diagnosis of LA requires a high degree of suspicion. Many other manifestations should arouse this high degree of suspicion for LA apart from recurrent fetal loss, including unexplained thrombocytopenia, pulmonary hypertension, history of thrombotic events, cerebral vascular diseases in the young, unexplained infertility, autoimmune hemolytic anemia, thrombotic endocarditic mimicking rheumatic heart disease without history, and other features of rheumatic fever.

This high prevalence cannot be solely attributable to primary APS bearing in mind the heterogeneous nature of the antibody and the protean manifestation of its clinical picture. As enumerated by Greaves ${ }^{7}$ LA is also detectable in association with infections, ie, viral infections such as HIV-1, varicella, and hepatitis C, bacteria infections such as syphilis, and parasitic infections such malaria, which is endemic in this part of the world. Also various drugs such as guanidine, hydralazine, procainamide, and phenytoin may be responsible, as may be miscellaneous associations such as sickle cell disease, autoimmune hemolytic anemia, and autoimmune thrombocytopenia. Therefore strong relevant clinical information is required to make a meaningful decision.

\section{Disclosure}

The authors declare no conflicts of interest.

\section{References}

1. Vietkamp H, Kerkhoven P, Leoliger EA. Circulating antivoagulant in disseminating lupus erythematosus. Proposed mode of action. Haemostasis. 1974;2:253-259.

2. Conley CL, Harman RC. A haemorrhagic disorder caused by circulating anticoagulant in patients with disseminated lupus erythematosus. J Clin Invest. 1952;31:621-622.

3. Bowie EJW, Thompson JH Jr, Pascuzzi CA, Owen CA Jr. Thrombosis in systemic lupus erythematosus despite circulating anticoagulant. J Lab Clin Med. 1963;62:416-430.

4. Boey ML, Colaco GB, Gharvi AE, et al. Thrombosis in systemic lupus erythematosus: striking association with the presence of circulating anticoagulants. Br Med J. 1983;287:1021-1023.

5. Angles-Cano E, Sultan Y, Clauvel JP. Predisposing factors to thrombosis in systemic lupus erythematosus. Possible relation to endothelial cell damage. J Lab Clin Med. 1979;94:312-323.

6. Parazzini FB, Faden D, et al. Antiphospholipid antibodies and recurrent miscarriage. Obst Gynaecol. 1991;77:854-858.

7. Greaves M. Antiphospholipid antibodies and thrombosis. Lancet. 1999; 353:1348-1353.

8. Nachman RL, Scliverstein R. Hypercoagulable states. Am Intern Med. 1993;199:819-827.

9. Hayslett JP. The effect of SLE on pregnancy and pregnancy outcome. Am J Reprod Immunol. 1992;28:199-204.

10. Branch DW. Thoughts on the mechanism of pregnancy loss associated with the antiphospholipid syndrome. Lupus. 1994;3:275-280.

11. Ouick AJ. The Haemorrhagic Diseases and the Physiology of Haemostasis. Springfield, Illinois: Charles C Thomas; 1942.

12. Proctor RR, Rapparport SI. The partial thromboplastin time with kaolin. A simple screening test for the first stage plasma clotting factor deficiencies. Am J Clin Pathol. 1961;36:212.

13. Exner T, Rikard KA, Kroneuberg HA. Sensitive tests demonstrating lupus anticoagulant and its behavioral patterns. Br H Haematol. 1978; 5:81-92.

14. Dacie JV, Lewis SM, editors. Practical Haematology, 8th ed. Edinburgh: Churchill Livingstone; 1994:351-354.

15. Sammaritano LR, Gharavi AE, Lockshin MD. Antiphospholipd antibody syndrome: immunologic and clinical aspects. Semin Arthritis Rheum. 1990;20:81-96. 
16. Alarcon Segovia D, Perez-Vasquez ME, Villa AR, Drenkard C, Cabieddes J. Preliminary classification criteria for the antiphospholipid syndrome within systemic lupus erythematosus. Semin Arthritis Rheum. 1992;21-27:275-286.

17. Levy RA, Gharavi AE, Sammaritano LR, Qamar T, Habina LM, Lockshin M. IgG antiphospholipid antibodies of patients with SLE and with syphilis differ. J Rheumatol. 1990;17:1036-1041.

18. Hunt JE, McNeil HP, Morgan GJ, Crameri RM, Krilis SA. A phospholipids -beta- glycoprotein 1 is an antigen for anticardiolipin antibodies occurring in autoimmune disease but not with infection. Lupus. $1992 ; 1: 75-81$

19. Greisman SG, Thayaparan RS, Godwin TA, Lockshin MD. Occlusive vasculopathy in systemic lupus erythematosus: association with anticardiolipin antibody. Arch Intern Med. 1991;151:389-392.

20. Amengual O, Atsumi T, Khamashta MA, Hughes GRV. The role of the tissue factor pathway in the hypercoagulable states in patients antiphospholipid syndrome. Thromb Haemost. 1998;79:276-281.

21. Lindsey NJ, Henderson FI, Malla R, Milford-Ward M, Greaves M, Hughes P. Inhibition of prostacyclin release by endothelial binding anticardiolipin antibodies in thrombosis-prone patient with systemic lupus erythematosus and the antiphospholipid syndrome. $\mathrm{Br} J$ Rheumatol. 1994;33:20-26.
22. Lindsey NJ, Dawson RA, Henderso FI, Greaves M, Hughes P. Simultaneous von Willebrand antigen release by immunoglobulin by thrombosis-prone patients with systemic lupus erythematosus and antiphospholipid syndrome. Br J Rheumatol. 1993;32:123-126.

23. Rand JH, Wu XX, Andree HA, et al. Pregnancy loss in the antiphospholipid antibody syndrome:a possible thrombogenic mechanism. N Engl J Med. 1997;337:154-160.

24. Della valle $\mathrm{P}$, Crippa L, Safa O, et al. Potential failure of the international normalized ratio (INR) system in the monitoring of oral anticoagulation in patients with lupus anticoagulant. Ann Med Intern. 1996; 147(Suppl 1):10-14.

25. Moil S, Ortel TL. Monitoring warfarin therapy in patients with Lupus anticoagulant. Ann Med Intern. 1997;127:477-485.

26. Haywood L, Brown MD. Antiphospholipid antibodies and recurrent pregnancy loss. Clin Obst Gynecol. 1991;34:1-17.

\section{Publish your work in this journal}

The Journal of Blood Medicine is an international, peer-reviewed, open access, online journal publishing laboratory, experimental and clinical aspects of all topics pertaining to blood based medicine including but not limited to: Transfusion Medicine; Blood collection, Donor issues, Transmittable diseases, and Blood banking logistics; Immunohematology; Artificial and alternative

\section{Dovepress}

blood based therapeutics; Hematology; Biotechnology/nanotechnology of blood related medicine; Legal aspects of blood medicine; Historical perspectives. The manuscript management system is completely online and includes a very quick and fair peer-review system. Visit http://www.dovepress.com/ testimonials.php to read real quotes from published authors. 